\title{
Creating a Validated Simulation Training Curriculum in Otolaryngology
}

\author{
Sanjana Bhalla ${ }^{1}$ Neil Tolley ${ }^{2} \cdot$ Zaid Awad $^{2}$ \\ Published online: 27 February 2020 \\ (C) The Author(s) 2020
}

\begin{abstract}
Purpose of Review Simulation-based training is an integral component of surgical training. It allows practice of technical skills within a safe environment without compromising patient safety. This article seeks to review current virtual and non-virtual reality simulation models within the literature and review their validation status.

Recent Findings Many simulation models exist within otolaryngology and are currently being used for education. New models are also continuously being developed; however, validity should be proven for the models before incorporating their use for educational purposes. Validity should be determined by experts and trainees themselves.

Summary A validated simulation curriculum should be incorporated within the otolaryngology training programme. A curriculum based on the current training programme at our institution serves as an exemplar for local adoption.
\end{abstract}

Keywords Simulation $\cdot$ Otolaryngology $\cdot$ Training $\cdot$ Curriculum $\cdot$ Validation

\section{Introduction}

The benefits of simulation training have been well documented in medical education, as well as other industries such as aviation and military services. Time for training has been affected in recent years due to continuing changes in the healthcare system [1-3]. Barriers to learning include infrequent training opportunities as well as societal pressures for increased patient safety. Learning and practising skills by novices on any patient raise patient safety concerns [4].

Operative experience is essential in acquiring surgical skills and the time in which trainees have to gain these experiences has changed due to a variety of factors including reduced training opportunities and a restriction of working hours.

Simulation allows a safe platform for education and assessment where there is deliberate practice under supervision as

This article is part of the Topical Collection on Simulation Training in Otolaryngology

Neil Tolley

n.tolley@imperial.ac.uk

1 Department of Otolaryngology, Imperial College Healthcare NHS Trust, St Mary's Hospital, London, UK

2 Department of Otolaryngology and head and neck cancer, Imperial College London, London, UK well as determining competency without compromising patient safety. This is becoming increasingly important as a recent study from John Hopkins University suggests that medical error is the third leading cause of death in the USA [5]. In the UK, the annual report in 2017/2018 showed that the NHS spent $£ 1.95$ billion in clinical negligence claims [6].

Many other specialties have successfully integrated simulation-based education opportunities into their curriculum [4] and simulation-based education is now considered an integral component of surgical training [7].

In a recent review, simulation resulted in reduced surgical time and higher performance rates for laparoscopic surgery when compared with traditional teaching methods [8]. Simulation-based teaching has led to improved patient outcomes in many clinical settings including technical skills and crisis situations [9], as well as allowing time for reflection with the assurance of patient safety [10].

\section{Simulation in Otolaryngology Training}

The current cohort of surgical trainees are required to gain the same surgical competencies as previous generations during a time of limited operative exposure, reduced trainee-trainer interaction time and increased workload of supervising surgeons $[2,3,11,12]$. 
In the UK, the Otolaryngology curriculum currently requires trainees to show competence in performing key indicative procedures before completion of training. The Joint Committee on Surgical Training (JCST) states that all trainees seeking certification in otolaryngology specifically must obtain, as an absolute minimum, ten of the following procedures as the principal surgeon: mastoidectomy, major neck surgery, tracheostomies, paediatric endoscopies, septorhinoplasties, endoscopic sinus surgery and removal of foreign bodies from the upper aerodigestive tract. The methods in which these procedures are acquired are by practical teaching, observing, assisting and operating under supervision. No uniformity or proven validity exists for any of these methods.

All simulated platforms aim to consolidate techniques and accelerate skill acquisition needed to complete training, without compromising patient safety [13]. Simulation within otolaryngology is not a new concept. Cadaveric temporal bone dissection for training in mastoid surgery is one of the oldest simulators $[14,15]$.

Currently, due to the limited access to live animal and cadaveric human tissue imposed by the Human Tissue Act [16], many practical otolaryngology courses use alternative platforms as simulators. These include physical "task trainers" and computer-assisted virtual reality platforms, which have been and are in the process of development. However, many of these models have not yet been validated [17•].

Trainees have engaged with practical skills courses including simulated training platforms such as animal models, cadavers and synthetic material for several decades. There are many descriptive studies in the literature. However attempts to validate the models are less evident [18] and there is no standardisation in the method of validation of such training platforms. In addition, although a model may not appear realistic, it can still be used to achieve desired training by enhancing the skill in question [13]; this has led to the development of low-cost trainers for skill transference.

\section{How to Validate Simulation Models}

As simulators vary and teach different skill sets, this makes it difficult to validate the models in a uniform way. The European Association for Endoscopic Surgery produced guidelines to outline the keystones of simulator validation [19•].

Face validity reflects the ability of a simulator to produce a realistic environment that resembles the actual surgical procedure, and can be assessed by the trainer and trainee.

Content validity is the ability of the simulator to deliver what is expected to be achieved, which can be done by satisfying pre-determined learning objectives. This can then be subdivided into global, task-specific, construct, predictive and concurrent validity. Construct validity can be used to differentiate between different levels of expertise amongst participants and is essential prior to incorporating models into training to use them on a regular basis. Predictive validity can be used to predict future performance. Concurrent validity is used to how a model compares with another that has already been validated or considered as a gold standard. Transfer validity is used to ascertain whether the simulator has the effect it proposes to have [20].

Validity can be measured via a structure questionnaire or via physical measurements of size, durability or use of instruments $[21,22]$.

As well as validating simulation models practically, simulation-based teaching is also important to develop nontechnical skills of trainees. A recent study showed that senior trainees valued the non-technical skills of communication, leadership and teamwork [23] within simulation-based training.

\section{Validated Simulation in Otolaryngology}

Simulators can be broadly divided into virtual reality (VR) and non-virtual reality (non-VR) simulators. Nonvirtual reality simulators include human, animal and artificial models. These simulators remain popular as they have been used for a long time and are generally affordable and reproducible.

Human cadavers provide the greatest anatomical accuracy; however, there is lack of availability due to escalating costs and changes to the Human Tissue Act [16] as well as the lack of tissue realism due to the effect of formaldehyde on tissues and the absence of bleeding.

Dead animal tissue does not require any special licence within the UK except standard health and safety protocols. Compared with synthetic material, animal tissue offers greater realism of tissue handling and is far more affordable and accessible.

Non virtual reality simulators can be specific body parts or total body simulators, such as SimMan, SimNewB and SimBaby [24]. Other simulators relating to specific body parts can include animal/human tissue, task trainers or simulation mannequins including hybrid models. Full-body mannequins have been found to be useful in setting up complex patient scenarios [10] whereas partial body simulators are useful for task-specific training and are more practical with regard to portability and storage.

Otolaryngology is a speciality with a wide range of procedures, requiring different instruments and skills. In order to look at simulation within otolaryngology, skill sets needed to achieve global operative competence, sometimes irrespective of the anatomical area, need to be assessed. For this reason, we divided the syllabus procedures into: 
Table 1 Validated otology simulators

\begin{tabular}{|c|c|c|c|}
\hline Simulator & Model type & Type of validation & Study/studies \\
\hline Pettigrew temporal bone & non-VR & $\begin{array}{l}\text { Face } \\
\text { Content } \\
\text { Concurrent }\end{array}$ & Awad et al. [33] \\
\hline Temporal bone cadaver & non-VR & $\begin{array}{l}\text { Face } \\
\text { Content } \\
\text { Concurrent }\end{array}$ & Awad et al. [33] \\
\hline 3D artificial simulator & non-VR & Face & Mick et al. [35] \\
\hline 3D novel simulator & non-VR & Face & Mowry et al. [36] \\
\hline $3 \mathrm{D}$ isomorphic & non-VR & $\begin{array}{l}\text { Face } \\
\text { Content } \\
\text { Transfer }\end{array}$ & Hochman et al. [37] \\
\hline 3D temporal model A & non-VR & Face & Rose et al. [38] \\
\hline 3D temporal model B & non-VR & Face & Rose et al. [38] \\
\hline Acrylic synthetic resin replica & non-VR & Face & Okada et al. [40] \\
\hline 3D PHACON & non-VR & $\begin{array}{l}\text { Face } \\
\text { Content }\end{array}$ & Da Cruz and Francis [34] \\
\hline Myringotomy with VTI & non-VR & Construct & Volsky et al. [25] \\
\hline Temporal bone model & non-VR & $\begin{array}{l}\text { Transfer } \\
\text { Construct }\end{array}$ & Togerson et al. [41] \\
\hline Surgical myringotomy model & non-VR & $\begin{array}{l}\text { Face } \\
\text { Transfer }\end{array}$ & Hong et al. [27] \\
\hline Malekzadeh model & non-VR & $\begin{array}{l}\text { Face } \\
\text { Content } \\
\text { Transfer }\end{array}$ & $\begin{array}{l}\text { Malekzadeh et al. [26] } \\
\text { Mahalingham et al. [42] }\end{array}$ \\
\hline Jesudason Bradford training model & non-VR & $\begin{array}{l}\text { Face } \\
\text { Content }\end{array}$ & Mahalingham et al. [42] \\
\hline Duijvestein Bradford training model & non-VR & $\begin{array}{l}\text { Face } \\
\text { Content }\end{array}$ & Mahalingham et al. [42] \\
\hline Wigan trainer model & non-VR & $\begin{array}{l}\text { Face } \\
\text { Content }\end{array}$ & Mahalingham et al. [42] \\
\hline Surgical skills box & non-VR & $\begin{array}{l}\text { Face } \\
\text { Content }\end{array}$ & Mahalingham et al. [42] \\
\hline 3D surgical middle ear simulator stapedectomy model & non-VR & Face & Monfared et al. [29] \\
\hline University of Western myringotomy with haptic feedback & VR & $\begin{array}{l}\text { Face } \\
\text { Content }\end{array}$ & $\begin{array}{l}\text { Sowerby et al. [43] } \\
\text { Ho et al. [44] }\end{array}$ \\
\hline Haptic voxel-based virtual model & VR & $\begin{array}{l}\text { Face } \\
\text { Content } \\
\text { Transfer }\end{array}$ & Hochman et al. [45] \\
\hline University of Western myringotomy with optical feedback & VR & $\begin{array}{l}\text { Face } \\
\text { Content }\end{array}$ & Wheeler et al. [46] \\
\hline Western myringotomy simulator & VR & $\begin{array}{l}\text { Face } \\
\text { Content }\end{array}$ & Huang et al. [47] \\
\hline Stanford temporal bone surgical simulator & VR & Construct & Sewell et al. [48] \\
\hline Mediseus temporal bone simulator & VR & $\begin{array}{l}\text { Face } \\
\text { Content } \\
\text { Construct } \\
\text { Transfer }\end{array}$ & $\begin{array}{l}\text { Zhao et al. [49] } \\
\text { Zhao et al. }[50,51] \\
\text { O'leary et al. [52] }\end{array}$ \\
\hline Ohio State University simulator & VR & Transfer & Wiet et al. [53] \\
\hline VOXEL-MAN TempoSurg & VR & $\begin{array}{l}\text { Face } \\
\text { Content }\end{array}$ & $\begin{array}{l}\text { Reddy-Kolanu and Alderson [54] } \\
\text { Arora et al. [38] } \\
\text { Nash et al. [55] }\end{array}$ \\
\hline
\end{tabular}


Table 1 (continued)

\begin{tabular}{|c|c|c|c|}
\hline Simulator & Model type & Type of validation & Study/studies \\
\hline & & \multirow{4}{*}{ Construct } & Francis et al. [56] \\
\hline & & & Khemani et al. [57] \\
\hline & & & Zirkle et al. [58] \\
\hline & & & Linke et al. [59] \\
\hline Visible ear simulator & VR & & Andersen et al. [60] \\
\hline
\end{tabular}

$V R$ virtual reality, non- $V R$ non-virtual reality

Reprinted from Musbahi O. et al. [133••], with permission from Elsevier

- Otology, including microscopic, endoscopic and open procedures

- Airway and throat, including trans-oral aerodigestive surgery and open procedures

- Rhinology, including endonasal, endoscopic and open procedures

\section{Otology Simulators}

Otology is probably the most developed subspecialty within otolaryngology with regard to simulation (Table 1). Myringotomy and grommet insertion is one of the commonest otolaryngology procedures and there are many physical simulators for it. Most models are inexpensive, easily made and reproducible [25-28]. Other physical otology models are also available including 3D models for mastoidectomy, stapedectomy and various other middle ear surgeries [29-32].

Cadaveric temporal bone dissection has been used for mastoidectomy training for many years with high validity $[14,15]$. However, due to limitations of cadaveric material, synthetic temporal bones have been developed for training such as the Pettigrew temporal bone with variable success [33]. There have been other non-virtual reality models that have been developed for temporal bone drilling, with different forms of validation [34-38].

Otology as a subspecialty has the most virtual reality simulators available. Arora et al. [39] demonstrated that the incorporation of temporal bone virtual reality simulation into the otolaryngology curriculum is beneficial especially for junior trainees.

\section{Airway and Throat Simulators}

There are several simulators for airway and laryngology, including biologic tissue (porcine or ovine models) and nonbiologic training models [61-78]. These models have been used for intubation skills and removal of airway foreign body as well as microlaryngoscopic procedures.
Other models have been developed for ligation of vessels during tonsillectomy [82-85], drainage of peritonsillar abscess [86-89] and facial local flap reconstruction [90-92].

Few virtual reality airway simulators are reported in the literature. Some of these allow the practice of flexible bronchoscopy [93-97] and provide haptic feedback. However, these have not been validated.

\section{Rhinology Simulation}

Endoscopic sinus surgery (ESS) is one of the key skills in otolaryngology training and it lends itself very well to simulation. Biologic models have traditionally been used. Ovine models have been used for ESS training before due to similarity in human anatomy [98], and demonstrated that this model achieved face and content validity as well as discriminating between different experience levels of participants therefore demonstrating construct validity of this model. It has been the largest study to our knowledge which looked at alternative methods for ESS training [99, 100].

Due to cost and storage, other physical models have been developed and tested as task trainers [101-103]. These may use biologic or non-biologic materials. The low-cost task trainer described by Malekzadeh et al. [101] allows trainees to perform removing fluid from maxillary sinus and targeted injections. This has achieved face, content and construct validity, and is an easily affordable model. This demonstrates skill transference as mentioned previously.

Non-virtual reality models have been developed for tasks such as epistaxis [104-106].

Sinus procedures lend themselves well to virtual reality simulation due to heavy instrumentation; therefore, these simulators allow more analysis and feedback as they are computer generated [90]. Simulators allowing procedures such as nasendoscopy [107-109] and FESS [110] have been developed.

The ES3 simulator was developed [110] and has been the most extensively validated [111-115], namely construct and predictive validity. It allows training for scope manipulation, mucosal injection, middle turbinate medialisation, 
uncinectomy and maxillary antrostomy. The Dextroscope endoscopic sinus simulator tested face, content and predictive validity [108]; however, the rating for learning manual skills was rated poorly (Table 2).

\section{Other Simulations Within Otolaryngology}

Due to robotic surgery developing within otolaryngology, models have been developed so trainees can gain appropriate
Table 2 Validated rhinology, airway and throat simulators

\begin{tabular}{|c|c|c|c|}
\hline Simulator & $\begin{array}{l}\text { Model } \\
\text { type }\end{array}$ & $\begin{array}{l}\text { Type of } \\
\text { validation }\end{array}$ & Study \\
\hline \multirow[t]{5}{*}{ ES3 endoscopic sinus surgery simulator } & \multirow[t]{5}{*}{ VR } & $\begin{array}{l}\text { Face } \\
\text { Construct }\end{array}$ & Arora et al. [116] \\
\hline & & \multirow[t]{4}{*}{ Transfer } & Fried et al. [114] \\
\hline & & & Rudman et al. [117] \\
\hline & & & Edmond Jr. [110] \\
\hline & & & Freid et al. [111] \\
\hline Dextroscope & VR & Transfer & Caversaccio et al. [108] \\
\hline McGill simulator for endoscopic sinus surgery & VR & $\begin{array}{l}\text { Face } \\
\text { Construct }\end{array}$ & Varshny et al. [118] \\
\hline Flinders Sinus simulator & VR & Construct & Diment et al. [119] \\
\hline Georgetown low-cost sinus trainer & non-VR & $\begin{array}{l}\text { Face } \\
\text { Content } \\
\text { Construct }\end{array}$ & Steehler et al. $[102,120]$ \\
\hline Low-fidelity sinus simulator & non-VR & $\begin{array}{l}\text { Construct } \\
\text { Transf } \\
\text { er }\end{array}$ & Leung et al. [121] \\
\hline Sheep head rhinology model & non-VR & $\begin{array}{l}\text { Face } \\
\text { Content }\end{array}$ & Awad et al. [99] \\
\hline Ovine endoscopic sinus model & non-VR & Construct & Awad et al. [100] \\
\hline $\begin{array}{l}\text { High-fidelity, Massachusetts Eye and } \\
\text { Ear infirmary model }\end{array}$ & non-VR & $\begin{array}{l}\text { Face } \\
\text { Construct }\end{array}$ & Dedmon et al. [70] \\
\hline MedStar Washington & non-VR & $\begin{array}{l}\text { Face } \\
\text { Content }\end{array}$ & Holliday et al. [75] \\
\hline Porcine Model & non-VR & $\begin{array}{l}\text { Face } \\
\text { Content }\end{array}$ & Awad et al. [71] \\
\hline Laryngeal dissection module, Emory University & non-VR & $\begin{array}{l}\text { Construct } \\
\text { Transfer }\end{array}$ & Contag et al. [74] \\
\hline Operating Room Immersive Microlaryngology & non-VR & $\begin{array}{l}\text { Face } \\
\text { Construct }\end{array}$ & Fleming et al. [73] \\
\hline Transcervical Laryngeal Simulator Model & non-VR & $\begin{array}{l}\text { Face } \\
\text { Transfer }\end{array}$ & Ainsworth et al. [77] \\
\hline Peroral Vocal Fold injection simulation & non-VR & Transfer & Amin et al. [69] \\
\hline Modified Cricothyroidectomy trainer & non-VR & $\begin{array}{l}\text { Face } \\
\text { Content } \\
\text { Transfer }\end{array}$ & Cabrera-Muffy et al. [76] \\
\hline $\begin{array}{l}\text { Dundee Endoscopic Psychomotor } \\
\text { Otolaryngology Surgery Trainer }\end{array}$ & non-VR & Construct & Ross et al. [78] \\
\hline TraumaMan & non-VR & $\begin{array}{l}\text { Content } \\
\text { Transfer }\end{array}$ & Walsh et al. [79] \\
\hline Porcine model SimMan & non-VR & $\begin{array}{l}\text { Transfer } \\
\text { Construct } \\
\text { Face }\end{array}$ & $\begin{array}{l}\text { Hall [80] } \\
\text { John et al. [24] }\end{array}$ \\
\hline Low-fidelity cricothyroidotomy simulator & non-VR & Construct & Aho et al. [81] \\
\hline
\end{tabular}

$V R$ virtual reality, non- $V R$ non-virtual reality

Reprinted from Musbahi O. et al. [133••], with permission from Elsevier 
training in this [123-125]; the model allows trainees to practise on da Vinci controls.

There has also been development of models for subtotal or intracapsular tonsillectomies [126] and for FNA of thyroid lesions [127]; however, to our knowledge, these have not been validated. Other physical models have been developed to allow practice of robotic surgery setup [128], rigid oesophagoscopy [129] and neck dissection [130].

For the purpose of this review, we have focussed on validated models; however, it should be noted there are other simulated platforms which have been developed which have not yet been validated. The teams that use these models should be encouraged to validate them as outlined above.

\section{Selecting Models for a Particular Curriculum}

A simulation curriculum should cover the competencies required for completion of training. Currently at Imperial College London, a simulation programme for North Thames ST3-ST5s runs annually. Work-based assessments (WBA) are part of the ISCP curriculum for CT1-ST8s. These can take the format of procedure-based assessments (PBA), direct observation of procedural skills (DOPS), clinical evaluation exercise (CEX) and case-based discussion (CBD) [131]. Awad et al. [132••] showed over a period of 6 years, 3264 procedure-based assessments were submitted, and these were by far the most popular form of WBA. Common procedures assessed using PBA included tonsillectomy, microlaryngoscopy and endoscopic sinus surgery. Therefore, the focus on a technique for a practical assessment tool is warranted, and this can be achieved by validated simulation platforms. Programme directors may choose different simulated training platforms depending on facilities, faculty and funding.

\section{Conclusion}

Simulation is a continually developing field within otolaryngology training. Due to reduced operative experience, it is crucial that trainees have adequate exposure to the core procedures they will be experiencing as a registrar and are required to perform to complete their training. In addition, simulation is also useful for practising real-life scenarios that trainees will commonly encounter during training. We believe a national simulation-based training programme should be developed and offered to all trainees with focus on different skills required at that level of training, whether it be technical or non-technical operative skills. In addition, a regular simulation-based training programme will allow development of simulators within otolaryngology to continuously improve educational opportunities for trainees.

\section{Compliance with Ethical Standards}

Conflict of Interest The authors declare that they have no conflict of interest.

Human and Animal Rights and Informed Consent This article does not contain any studies with human or animal subjects performed by any of the authors.

Open Access This article is licensed under a Creative Commons Attribution 4.0 International License, which permits use, sharing, adaptation, distribution and reproduction in any medium or format, as long as you give appropriate credit to the original author(s) and the source, provide a link to the Creative Commons licence, and indicate if changes were made. The images or other third party material in this article are included in the article's Creative Commons licence, unless indicated otherwise in a credit line to the material. If material is not included in the article's Creative Commons licence and your intended use is not permitted by statutory regulation or exceeds the permitted use, you will need to obtain permission directly from the copyright holder. To view a copy of this licence, visit http://creativecommons.org/licenses/by/4.0/.

\section{References}

Papers of particular interest, published recently, have been highlighted as:

- Of importance

•. Of major importance

1. Simpson C, Cottam H, Fitzgerald JE, Giddings CE. The European working time directive has a negative impact on surgical training in the UK. The Surgeon. 2011;9(1):56-7.

2. Anwar M, Irfan S, Daly N, Amen F. EWTD has negative impact on training for surgeons. Bmj. 2005;331(7530):1476.

3. Fitzgerald JE, Giddings CE, Khera G, Marron CD. Improving the future of surgical training and education: consensus recommendations from the Association of Surgeons in Training.

4. Nguyen LH, Bank I, Fisher R, Mascarella M, Young M. Managing the airway catastrophe: longitudinal simulation-based curriculum to teach airway management. J Otolaryngol. 2019;48(1):10.

5. Makary MA, Daniel M. Medical error - the third leading cause of death in the US. Bmj. 2016;353:i2139.

6. Foy MA. What is happening to clinical negligence claims in the NHS? A financial crisis for the future? Bone \& Joint 360. 2017;6(6):41-3.

7. Rosenthal R, Gantert WA, Hamel C, Metzger J, Kocher T, Vogelbach P, et al. The future of patient safety: surgical trainees accept virtual reality as a new training tool. Patient Safety Surg. 2008;2(1): 16.

8. Cote V, Nguyen L, Richardson K 2009. Advanced airway management teaching in otolaryngology residency: a survey of residents across canada: 11: 20-11: 28. Journal of Otolaryngology: Head and Neck Surgery. May 1;38:S5-6.

9. McGaghie WC, Draycott TJ, Dunn WF, Lopez CM, Stefanidis D. Evaluating the impact of simulation on translational patient outcomes. Simul. Healthc. 2011;6(Suppl):S42.

10. Javia L, Sardesai MG. Physical models and virtual reality simulators in otolaryngology. Otolaryngol. Clin. N. Am. 2017;50(5): 875-91. 
11. Intercollegiate Surgical Curriculum Programme. Allum W ISCP management group ISCP evaluation report June. Available at: http://www.jcst.org/ISCP!Evaluation!/full_evaluation_report ().

12. Hartle A, Gibb S, Goddard A. Can doctors be trained in a 48 hour working week? Bmj. 2014;349:g7323.

13. Machines, mannikins and polo mints. Chief Medical Officer's Annual Report 2008. Available at: http://webarchive. nationalarchives.gov.uk/20130107105354/http:/www.dh.gov.uk/ prod_consum_dh/groups/dh_digitalassets/documents/digitalasset/ dh_096231.pdf.

14. George AP, De R. Review of temporal bone dissection teaching: how it was, is and will be. J. Laryngol. Otol. 2010;124(2):119-25.

15. Clifton N, Klingmann C, Khalil $\mathrm{H}$. Teaching otolaryngology skills through simulation. Eur. Arch. Otorhinolaryngol. 2011;268(7): 949-53.

16. Human Tissue Authority. Human Tissue Act 2004. Available at: http://www.hta.gov.uk/legislationpoliciesandcodesofpractice/ legislation/humantissueact.cf. Updated 2004.

17. Javia L, Deutsch ES. A systematic review of simulators in otolaryngology. Otolaryngol. Head Neck Surg. 2012;147(6):999-1011 An original systematic review of early simulators within otolaryngology training.

18. Sargent RG. Verification and validation of simulation models. J Siimul. 2013;7(1):12-24.

19. Carter FJ, Schijven MP, Aggarwal R, Grantcharov T, Francis NK, Hanna GB, et al. Consensus guidelines for validation of virtual reality surgical simulators. Surg. Endosc. Other Interv. Tech. 2005;19(12):1523-32 An article describing how to validate simulation models.

20. McDougall EM. Validation of surgical simulators. J. Endourol. 2007;21(3):244-7.

21. Kotby MN, Wahba HA, Kamal E, El-Makhzangy AM, Bahaa N. Animal model for training and improvement of the surgical skills in endolaryngeal microsurgery. J. Voice. 2012;26(3):351-7.

22. Stasche N, Quirrenbach T, Bärmann M, Krebs M, Harrass M, Friedrich K. IMOLA-a new larynx model for surgical training. Education in transoral laser microsurgery of the upper airways. Hno. 2005;53(10):869-72.

23. Deutsch ES, Malloy KM, Malekzadeh S. Simulation-based otorhinolaryngology emergencies boot camp: part 3: complex teamwork scenarios and conclusions.

24. John B, Suri I, Hillermann C, Mendonca C. Comparison of cricothyroidotomy on manikin vs. simulator: a randomised cross-over study. Anaesthesia. 2007;62(10):1029-32.

25. Volsky PG, Hughley BB, Peirce SM, Kesser BW. Construct validity of a simulator for myringotomy with ventilation tube insertion. Otolaryngol. Head Neck Surg. 2009;141(5):603-8.

26. Malekzadeh S, Hanna G, Wilson B, Pehlivanova M, Milmoe G. A model for training and evaluation of myringotomy and tube placement skills. Laryngoscope. 2011;121(7):1410-5.

27. Hong P, Webb AN, Corsten G, Balderston J, Haworth R, Ritchie $\mathrm{K}$, et al. An anatomically sound surgical simulation model for myringotomy and tympanostomy tube insertion. Int. J. Pediatr. Otorhinolaryngol. 2014;78(3):522-9.

28. Estomba CC, García JM, Zavarce MH, Reinoso FB. The Vigo grommet trainer. Eur. Ann. Otorhinolaryngol. Head Neck Dis. 2015;132(1):53-5.

29. Monfared A, Mitteramskogler G, Gruber S, Salisbury JK Jr, Stampfl J, Blevins NH. High-fidelity, inexpensive surgical middle ear simulator. Otol Neurotol. 2012;33(9):1573-7.

30. Clark MP, Westerberg BD, Mitchell JE. Development and validation of a low-cost microsurgery ear trainer for low-resource settings. J Laryngol Otol. 2016;130(10):954-61.

31. Barber SR, Kozin ED, Dedmon M, Lin BM, Lee K, Sinha S, et al. 3D-printed pediatric endoscopic ear surgery simulator for surgical training. Int. J. Pediatr. Otorhinolaryngol. 2016;90:113-8.
32. Anschuetz L, Bonali M, Ghirelli M, Mattioli F, Villari D, Caversaccio M, et al. An ovine model for exclusive endoscopic ear surgery. JAMA Otolaryngol. 2017;143(3):247-52.

33. Awad Z, Ahmed S, Taghi AS, Ghufoor K, Wareing MJ, Patel N, et al. Feasibility of a synthetic temporal bone for training in mastoidectomy: face, content, and concurrent validity. Otol Neurotol. 2014;35(10):1813-8.

34. Da Cruz MJ, Francis HW. Face and content validation of a novel three-dimensional printed temporal bone for surgical skills development. J Laryngol Otol. 2015;129(S3):S23-9.

35. Mick PT, Arnoldner C, Mainprize JG, Symons SP, Chen JM. Face validity study of an artificial temporal bone for simulation surgery. Otol Neurotol. 2013;34(7):1305-10.

36. Mowry SE, Jammal H, Myer C IV, Solares CA, Weinberger P. A novel temporal bone simulation model using $3 \mathrm{D}$ printing techniques. Otol Neurotol. 2015;36(9):1562-5.

37. Hochman JB, Rhodes C, Wong D, Kraut J, Pisa J, Unger B. Comparison of cadaveric and isomorphic three-dimensional printed models in temporal bone education. Laryngoscope. 2015;125(10):2353-7.

38. Rose AS, Kimbell JS, Webster CE, Harrysson OL, Formeister EJ, Buchman CA. Multi-material 3D models for temporal bone surgical simulation. Ann. Otol. Rhinol. Laryngol. 2015;124(7):528 36.

39. Arora A, Lau LY, Awad Z, Darzi A, Singh A, Tolley N. Virtual reality simulation training in otolaryngology. Int. J. Surg. 2014;12(2):87-94.

40. de Sousa AM, Okada DM, Suzuki FA. The use of simulators in the learning for otologic surgery. Arquivos Internacionais de Otorrinolaringologia. 2011;15(04):509-14.

41. Torgerson CS, Brydges R, Chen JM, Dubrowski A. Drilling simulated temporal bones with left-handed tools: a left-hander's right? Ann. Otol. Rhinol. Laryngol. 2007;116(11):819-26.

42. Mahalingam S, Awad Z, Tolley NS, Khemani S. Ventilation tube insertion simulation: a literature review and validity assessment of five training models. Clin. Otolaryngol. 2016;41(4):321-6.

43. Sowerby LJ, Rehal G, Husein M, Doyle PC, Agrawal S, Ladak HM. Development and face validity testing of a three-dimensional myringotomy simulator with haptic feedback. Journal of Otolaryngol. 2010;1:39(2).

44. Ho AK, Alsaffar H, Doyle PC, Ladak HM, Agrawal SK. Virtual reality myringotomy simulation with real-time deformation: development and validity testing. Laryngoscope. 2012;122(8): 1844-51.

45. Hochman JB, Rhodes C, Kraut J, Pisa J, Unger B. End user comparison of anatomically matched 3 -dimensional printed and virtual haptic temporal bone simulation: a pilot study. Otolaryngol. Head Neck Surg. 2015;153(2):263-8.

46. Wheeler B, Doyle PC, Chandarana S, Agrawal S, Husein M, Ladak HM. Interactive computer-based simulator for training in blade navigation and targeting in myringotomy. Comput. Methods Prog. Biomed. 2010;98(2):130-9.

47. Huang C, Cheng H, Bureau Y, Agrawal SK, Ladak HM. Face and content validity of a virtual-reality simulator for myringotomy with tube placement. Journal of Otolaryngology-Head \& Neck Surgery. 2015;44(1):40.

48. Sewell C, Morris D, Blevins NH, Dutta S, Agrawal S, Barbagli F, et al. Providing metrics and performance feedback in a surgical simulator. Computer Aided Surgery. 2008;13(2):63-81.

49. Zhao YC, Kennedy G, Hall R, O'leary S. Differentiating levels of surgical experience on a virtual reality temporal bone simulator. Otolaryngol. Head Neck Surg. 2010;143(5 suppl):30-5.

50. Zhao YC, Kennedy G, Yukawa K, Pyman B, O'Leary S. Improving temporal bone dissection using self-directed virtual reality simulation: results of a randomized blinded control trial. Otolaryngol. Head Neck Surg. 2011;144(3):357-64. 
51. Zhao YC, Kennedy G, Yukawa K, Pyman B, O’Leary S. Can virtual reality simulator be used as a training aid to improve cadaver temporal bone dissection? Results of a randomized blinded control trial. Laryngoscope. 2011;121(4):831-7.

52. O'Leary SJ, Hutchins MA, Stevenson DR, Gunn C, Krumpholz A, Kennedy G, et al. Validation of a networked virtual reality simulation of temporal bone surgery. Laryngoscope. 2008;118(6): 1040-6.

53. Wiet GJ, Stredney D, Kerwin T, Hittle B, Fernandez SA, AbdelRasoul M, et al. Virtual temporal bone dissection system: OSU virtual temporal bone system: development and testing. Laryngoscope. 2012;122(S1):S1-2.

54. Reddy-Kolanu G, Alderson D. Evaluating the effectiveness of the Voxel-Man TempoSurg virtual reality simulator in facilitating learning mastoid surgery. The Annals of The Royal College of Surgeons of England. 2011;93(3):205-8.

55. Nash R, Sykes R, Majithia A, Arora A, Singh A, Khemani S. Objective assessment of learning curves for the Voxel-Man TempoSurg temporal bone surgery computer simulator. J Laryngol Otol. 2012;126(7):663-9.

56. Francis HW, Malik MU, Varela DA, Barffour MA, Chien WW, Carey JP, et al. Technical skills improve after practice on virtualreality temporal bone simulator. Laryngoscope. 2012;122(6): 1385-91.

57. Khemani S, Arora A, Singh A, Tolley N, Darzi A. Objective skills assessment and construct validation of a virtual reality temporal bone simulator. Otol Neurotol. 2012;33(7):1225-31.

58. Zirkle M, Roberson DW, Leuwer R, Dubrowski A. Using a virtual reality temporal bone simulator to assess otolaryngology trainees. Laryngoscope. 2007;117(2):258-63.

59. Linke R, Leichtle A, Sheikh F, Schmidt C, Frenzel H, Graefe H, et al. Assessment of skills using a virtual reality temporal bone surgery simulator. Acta Otorhinolaryngol. Ital. 2013;33(4):27381.

60. Andersen SA, Mikkelsen PT, Konge L, Cayé-Thomasen P, Sørensen MS. Cognitive load in mastoidectomy skills training: virtual reality simulation and traditional dissection compared. J Surgic Educ. 2016;73(1):45-50.

61. Deutsch ES, Christenson T, Curry J, Hossain J, Zur K, Jacobs I. Multimodality education for airway endoscopy skill development. Ann. Otol. Rhinol. Laryngol. 2009;118(2):81-6.

62. Ianacone DC, Gnadt BJ, Isaacson G. Ex vivo ovine model for head and neck surgical simulation. Am. J. Otolaryngol. 2016;37(3):272-8

63. Howells TH, Emery FM, Twentyman JE. Endotracheal intubation training using a simulator: an evaluation of the Laerdal adult intubation model in the teaching of endotracheal intubation. Brit $\mathrm{J}$ Anaesthesia. 1973;45(4):400-2.

64. Hesselfeldt R, Kristensen MS, Rasmussen LS. Evaluation of the airway of the SimMan ${ }^{\mathrm{TM}}$ full-scale patient simulator. Acta Anaesthesiol. Scand. 2005;49(9):1339-45.

65. Schebesta K, Hüpfl M, Ringl H, Machata AM, Chiari A, Kimberger O. A comparison of paediatric airway anatomy with the SimBaby high-fidelity patient simulator. Resuscitation. 2011;82(4):468-72.

66. Sawyer T, Strandjord TP, Johnson K, Low D. Neonatal airway simulators, how good are they? A comparative study of physical and functional fidelity. J. Perinatol. 2016;36(2):151-6.

67. Latif R, Bautista A, Duan X, Neamtu A, Wadhwa A, Wu D, Carter $\mathrm{M}$, Akca O. Teaching advanced airway management skills: using simulation to accelerate the fiberoptic intubation learning curve. In Critical care medicine 2010 (Vol. 38, No. 12, pp. U136-U13〉). Philadelphia: Lippincott Williams \& Wilkins.
68. Smith ME, Leung BC, Sharma R, Nazeer S, McFerran DJ. A randomized controlled trial of nasolaryngoscopy training techniques. Laryngoscope. 2014;124(9):2034-8.

69. Amin M, Rosen CA, Simpson CB, Postma GN. Hands-on training methods for vocal fold injection education. Ann. Otol. Rhinol. Laryngol. 2007;116(1):1-6.

70. Dedmon MM, Paddle PM, Phillips J, Kobayashi L, Franco RA, Song PC. Development and validation of a high-fidelity porcine laryngeal surgical simulator. Otolaryngol. Head Neck Surg. 2015;153(3):420-6.

71. Awad Z, Patel B, Hayden L, Sandhu GS, Tolley NS. Simulation in laryngology training; what should we invest in? Our experience with 64 porcine larynges and a literature review. Clin. Otolaryngol. 2015;40(3):269-73.

72. Nixon IJ, Palmer FL, Ganly I, Patel SG. An integrated simulator for endolaryngeal surgery. Laryngoscope. 2012;122(1):140-3.

73. Fleming J, Kapoor K, Sevdalis N, Harries M. Validation of an operating room immersive microlaryngoscopy simulator. Laryngoscope. 2012;122(5):1099-103.

74. Contag SP, Klein AM, Blount AC, Johns MM III. Validation of a laryngeal dissection module for phonomicrosurgical training. Laryngoscope. 2009;119(1):211-5.

75. Holliday MA, Bones VM, Malekzadeh S, Grant NN. Low-cost modular phonosurgery training station: development and validation. Laryngoscope. 2015;125(6):1409-13.

76. Cabrera-Muffly C, Clary MS, Abaza M. A low-cost transcervical laryngeal injection trainer. Laryngoscope. 2016;126(4):901-5.

77. Ainsworth TA, Kobler JB, Loan GJ, Burns JA. Simulation model for transcervical laryngeal injection providing real-time feedback. Ann. Otol. Rhinol. Laryngol. 2014;123(12):881-6.

78. Ross PD, Steven R, Zhang D, Li H, Abel EW. Computer-assessed performance of psychomotor skills in endoscopic otolaryngology surgery: construct validity of the Dundee Endoscopic Psychomotor Otolaryngology Surgery Trainer (DEPOST). Surg. Endosc. 2015;29(11):3125-31.

79. Walsh R, Heiner J, Kang C, Hile D, Deering S. Emergency physician evaluation of a novel surgical cricothyroidotomy tool in simulated combat and clinical environments. Mil. Med. 2013;178(1):29-33.

80. Hall C, Andrew B. Randomized objective comparison of live tissue training versus simulators for emergency procedures. Am. Surg. 2011;77(5):561-5.

81. Aho JM, Thiels CA, AlJamal YN, Ruparel RK, Rowse PG, Heller SF, et al. Every surgical resident should know how to perform a cricothyrotomy: an inexpensive cricothyrotomy task trainer for teaching and assessing surgical trainees. J Surgic Educat. 2015;72(4):658-61.

82. Pearson CR, Wallace HC. The tonsil cup: a simple teaching aid for tonsillectomy. J Laryngol Otol. 1997;111(11):1064-5.

83. Duodu J, Lesser TH. Tonsil tie simulator. J Laryngol Otol. 2013;127(9):924-6.

84. Raja MK, Haneefa MA, Chidambaram A. Yorick's skull model for tonsillectomy tie training. Clin. Otolaryngol. 2008;33(2):1878.

85. Street I, Beech T, Jennings C. The Birmingham trainer: a simulator for ligating the lower tonsillar pole. Clin. Otolaryngol. 2006;31(1): 79.

86. Bunting H, Wilson BM, Malloy KM, Malekzadeh S. A novel peritonsillar abscess simulator. Simul. Healthc. 2015;10(5):320-5.

87. Scott GM, Fung K, Roth KE. Novel high-fidelity peritonsillar abscess simulator. Otolaryngol. Head Neck Surg. 2016;154(4): 634-7.

88. Taylor SR, Chang CD. Novel peritonsillar abscess task simulator. Otolaryngol. Head Neck Surg. 2014;151(1):10-3. 
89. Giblett N, Hari C. Introducing a realistic and reusable quinsy simulator. J Laryngol Otol. 2016;130(2):201-3.

90. Janus JR, Hamilton GS. The use of open-cell foam and elastic foam tape as an affordable skin simulator for teaching suture technique. JAMA facial plastic surg. 2013;15(5):385-7.

91. Gilmour A, Taghizadeh R, Payne CE. The educational hand and head: novel teaching tools in the design and execution of local flaps. J. Plast. Reconstr. Aesthet. Surg. 2012;65(7): 981-2.

92. Taylor SR, Chang CD. Gelatin facial skin simulator for cutaneous reconstruction. Otolaryngol. Head Neck Surg. 2016;154(2):27981.

93. Mandal S, Patel AR, Goldring JJ. P93 A simulated bronchoscopy course for new specialist trainees. Thorax. 2010;65(Suppl 4): A117.

94. Patel AR, Mandal S, Goldring JJ. P90 Simulated bronchoscopy training delivered by experienced peers improves confidence of new trainees. Thorax. 2010;65(Suppl 4):A116.

95. Pastis NJ, Vanderbilt AA, Tanner NT, Silvestri GA, Huggins JT, Svigals Z, et al. Construct validity of the Simbionix bronch mentor simulator for essential bronchoscopic skills. J Bronchol Intervent Pulmonol. 2014;21(4):314-21.

96. Vaidyanath C, Sharma M, Mistry V, Mendonca C. Orsim ${ }^{\mathrm{TM}}$ bronchoscopy simulator improves psychomotor skills for fibreoptic intubation amongst novices. Br. J. Anaesth. 2013;111(4):684-91.

97. Rowe R, Cohen RA. An evaluation of a virtual reality airway simulator. Anesth. Analg. 2002;95(1):62-6.

98. Gardiner Q, Oluwole M, Tan L, White PS. An animal model for training in endoscopic nasal and sinus surgery. J Laryngol Otol. 1996;110(5):425-8.

99. Awad Z, Touska P, Arora A, Ziprin P, Darzi A, Tolley NS. Face and content validity of sheep heads in endoscopic rhinology training. Int Forum Allergy Rhinol. 2014;4(10):851-8.

100. Awad Z, Taghi A, Sethukumar P, Tolley NS. Construct validity of the ovine model in endoscopic sinus surgery training. Laryngoscope. 2015;125(3):539-43.

101. Malekzadeh S, Pfisterer MJ, Wilson B, Na H, Steehler MK. A novel low-cost sinus surgery task trainer. Otolaryngol. Head Neck Surg. 2011;145(4):530-3.

102. Steehler MK, Chu EE, Na H, Pfisterer MJ, Hesham HN, Malekzadeh S. Teaching and assessing endoscopic sinus surgery skills on a validated low-cost task trainer. Laryngoscope. 2013;123(4):841-4.

103. Harbison RA, Johnson KE, Miller C, Sardesai MG, Davis GE. Face, content, and construct validation of a low-cost, non-biologic, sinus surgery task trainer and knowledge-based curriculum. Int Forum Allergy Rhinol. 2017;7(4):405-13.

104. Scott GM, Roth K, Rotenberg B, Sommer DD, Sowerby L, Fung $\mathrm{K}$. Evaluation of a novel high-fidelity epistaxis task trainer. Laryngoscope. 2016;126(7):1501-3.

105. Pettineo CM, Vozenilek JA, Kharasch M, Wang E, Aitchison P. Epistaxis simulator: an innovative design. Simul. Healthc. 2008;3(4):239-41.

106. Malekzadeh S, Deutsch ES, Malloy KM. Simulation-based otorhinolaryngology emergencies boot camp: part 2: special skills using task trainers.

107. Ecke U, Klimek L, Müller W, Ziegler R, Mann W. Virtual reality: preparation and execution of sinus surgery. Computer Aided Surgery. 1998;3(1):45-50.

108. Caversaccio M, Eichenberger A, Häusler R. Virtual simulator as a training tool for endonasal surgery. Am. J. Rhinol. 2003;17(5): 283-90.
109. Tolsdorff B, Pommert A, Höhne KH, Petersik A, Pflesser B, Tiede U, et al. Virtual reality: a new paranasal sinus surgery simulator. Laryngoscope. 2010;120(2):420-6.

110. Edmond CV Jr. Impact of the endoscopic sinus surgical simulator on operating room performance. Laryngoscope. 2002;112(7): 1148-58.

111. Fried MP, Sadoughi B, Weghorst SJ, Zeltsan M, Cuellar H, Uribe JI, et al. Construct validity of the endoscopic sinus surgery simulator: II. Assessment of discriminant validity and expert benchmarking. Arch Otolaryngol-Head Neck Surg. 2007;133(4): 350-7.

112. Gallagher AG, Cowie R, Crothers I, Jordan-Black JA, Satava RM. PicSOr: an objective test of perceptual skill that predicts laparoscopic technical skill in three initial studies of laparoscopopic performance. Surg. Endosc. Other Interv. Tech. 2003;17(9):1468-71.

113. Fried MP, Satava R, Weghorst S, Gallagher AG, Sasaki C, Ross D, et al. Identifying and reducing errors with surgical simulation. BMJ Qual. Saf. 2004;13(suppl 1):i19-26.

114. Fried MP, Sadoughi B, Gibber MJ, Jacobs JB, Lebowitz RA, Ross DA, et al. From virtual reality to the operating room: the endoscopic sinus surgery simulator experiment. Otolaryngol. Head Neck Surg. 2010;142(2):202-7.

115. Uribe SJI, Ralph WM Jr, Glaser AY, Fried MP. Learning curves, acquisition, and retention of skills trained with the endoscopic sinus surgery simulator. Am. J. Rhinol. 2004;18(2):87-92.

116. Arora H, Uribe J, Ralph W, Zeltsan M, Cuellar H, Gallagher A, et al. Assessment of construct validity of the endoscopic sinus surgery simulator. Arch Otolaryngol Head Neck Surg. 2005;131(3):217-21.

117. Rudman DT, Stredney D, Sessanna D, Yagel R, Crawfis R, Heskamp D, et al. Functional endoscopic sinus surgery training simulator. Laryngoscope. 1998;108(11):1643-7.

118. Varshney R, Frenkiel S, Nguyen LH, Young M, Del Maestro R, Zeitouni A, et al. The McGill simulator for endoscopic sinus surgery (MSESS): a validation study. J Otolaryngol. 2014;43(1):40.

119. Diment LE, Ruthenbeck GS, Dharmawardana N, Carney AS, Woods CM, Ooi EH, et al. Comparing surgical experience with performance on a sinus surgery simulator. ANZ J. Surg. 2016;86(12):990-5.

120. Steehler MK, Pfisterer MJ, Na H, Hesham HN, Pehlivanova M, Malekzadeh S. Face, content, and construct validity of a low-cost sinus surgery task trainer. Otolaryngol. Head Neck Surg. 2012;146(3):504-9.

121. Leung RM, Leung J, Vescan A, Dubrowski A, Witterick I. Construct validation of a low-fidelity endoscopic sinus surgery simulator. Am. J. Rhinol. 2008;22(6):642-8.

122. Wais M, Ooi E, Leung RM, Vescan AD, Lee J, Witterick IJ. The effect of low-fidelity endoscopic sinus surgery simulators on surgical skill. In International forum of allergy \& rhinology 2012 (Vol. 2, no. 1, pp. 20-26). Hoboken: Wiley Subscription Services, Inc., A Wiley Company.

123. Walliczek U, Förtsch A, Dworschak P, Teymoortash A, Mandapathil M, Werner J, et al. Effect of training frequency on the learning curve on the da Vinci Skills Simulator. Head Neck. 2016;38(S1):E1762-9.

124. Walliczek-Dworschak U, Mandapathil M, Förtsch A, Teymoortash A, Dworschak P, Werner JA, et al. Structured training on the da Vinci Skills Simulator leads to improvement in technical performance of robotic novices. Clin. Otolaryngol. 2017;42(1):71-80.

125. Zhang N, Sumer BD. Transoral robotic surgery: simulation-based standardized training. JAMA Otolaryngol. 2013;139(11):1111-7. 
126. Ruthenbeck GS, Tan SB, Carney AS, Hobson JC, Reynolds KJ. A virtual-reality subtotal tonsillectomy simulator. J Laryngol Otol. 2012;126(S2):S8-13.

127. Souza IA, Sanches C, Zuffo MK. A virtual reality simulator for training of needle biopsy of thyroid gland nodules. Studies in health technology and informatics. 2009;142:352-7.

128. Sperry SM, Weinstein GS. The University of Pennsylvania curriculum for training otorhinolaryngology residents in transoral robotic surgery. ORL. 2014;76(6):342-52.

129. Allak A, Liu YE, Oliynyk MS, Weng KH, Jameson MJ, Shonka DC Jr. Development and evaluation of a rigid esophagoscopy simulator for residency training. Laryngoscope. 2016;126(3): 616-9.

130. Griffin GR, Rosenbaum S, Hecht S, Sun GH. Development of a moderate fidelity neck-dissection simulator.

131. Intercollegiate Surgical Curriculum Programme. Tips for using procedure-based assessments (PBAs). https://www.iscp.ac.uk/ static/public/pba_tips.pdf ().
132.• Awad Z. A comprehensive evaluation of work and simulation based assessment in otolaryngology training (Doctoral dissertation, Imperial College London). General overview of simulation and work-based place assessments within otolaryngology curriculum.

133.• Musbahi O, Aydin A, Al Omran Y, Skilbeck CJ, Ahmed K. Current status of simulation in otolaryngology: a systematic review. J Surgic Educat. 2017;74(2):203-15 This is a systematic review of all recent otolaryngology simulators describing all manufacturers as well as number of participants from each study.

Publisher's Note Springer Nature remains neutral with regard to jurisdictional claims in published maps and institutional affiliations. 